\title{
Carcinogenicity Test
}

National Cancer Institute

\section{Source}

National Cancer Institute. Carcinogenicity Test. NCI Thesaurus. Code C15196.

An assay, usually performed on in vitro systems, in which the propensity of an agent to cause tumors is measured. 